\title{
A phase I pharmacokinetic and safety study of cabazitaxel in adult cancer patients with normal and impaired renal function
}

\author{
Analía Azaro $^{1,2} \cdot$ Jordi Rodón $^{1} \cdot$ Jean-Pascal Machiels ${ }^{3} \cdot$ Sylvie Rottey $^{4} \cdot$ \\ Silvia Damian ${ }^{5}$ Richard Baird $^{6} \cdot$ Javier Garcia-Corbacho $^{6} \cdot$ Ron H. J. Mathijssen $^{7}$. \\ Pierre-François Clot ${ }^{8}$ - Claudine Wack $^{8} \cdot$ Liji Shen $^{9}$ Maja J. A. de Jonge ${ }^{7}$
}

Received: 15 July 2016 / Accepted: 12 October 2016 / Published online: 27 October 2016

(c) The Author(s) 2016. This article is published with open access at Springerlink.com

\begin{abstract}
Purpose Limited data are available on cabazitaxel pharmacokinetics in patients with renal impairment. This openlabel, multicenter study assessed cabazitaxel in patients with advanced solid tumors and normal or impaired renal function.

Methods Cohorts A (normal renal function: creatinine clearance $[\mathrm{CrCL}]>80 \mathrm{~mL} / \mathrm{min} / 1.73 \mathrm{~m}^{2}$ ), B (moderate renal impairment: $\mathrm{CrCL} 30$ to $<50 \mathrm{~mL} / \mathrm{min} / 1.73 \mathrm{~m}^{2}$ ) and $\mathrm{C}$ (severe impairment: $\mathrm{CrCL}<30 \mathrm{~mL} / \mathrm{min} / 1.73 \mathrm{~m}^{2}$ ) received cabazitaxel $25 \mathrm{mg} / \mathrm{m}^{2}$ (A, B) or $20 \mathrm{mg} / \mathrm{m}^{2}$ (C) could be escalated to $25 \mathrm{mg} / \mathrm{m}^{2}$ ), once every 3 weeks. Pharmacokinetic parameters and cabazitaxel unbound fraction $\left(F_{\mathrm{U}}\right)$ were assessed using linear regression and mixed models. Geometric mean (GM) and GM ratios (GMRs) were determined using mean $\mathrm{CrCL}$ intervals (moderate and severe renal impairment: 40 and $15 \mathrm{~mL} / \mathrm{min} / 1.73 \mathrm{~m}^{2}$ ) versus a control $\left(90 \mathrm{~mL} / \mathrm{min} / 1.73 \mathrm{~m}^{2}\right)$.

Results Overall, 25 patients received cabazitaxel (median cycles: 3 [range 1-20]; Cohort A: 5 [2-13]; Cohort B: 3
\end{abstract}

Analía Azaro

aazaro@vhio.net; analiabeatriz.azaro@e-campus.uab.cat

1 Molecular Therapeutics Research Unit, Department of Medical Oncology, Vall d'Hebron University Hospital, Barcelona, Spain

2 Pharmacology Department, Universitat Autònoma de Barcelona (UAB), Barcelona, Spain

3 Department of Medical Oncology, Institut Roi Albert II, Cliniques Universitaires Saint-Luc and Institut de Recherche Clinique et Expérimentale (Pole MIRO), Université Catholique de Louvain, Brussels, Belgium

4 Department of Medical Oncology, University Hospital of Ghent and Heymans Institute of Pharmacology, Ghent University, Ghent, Belgium
[1-15]; and Cohort C: 5 [1-20]), of which 24 were eligible for pharmacokinetic analysis (eight in each cohort). For moderate and severe renal impairment versus normal renal function, GMR estimates were: clearance normalized to body surface area (CL/BSA) 0.95 (90\% CI 0.80-1.13) and 0.89 (0.61-1.32); area under the curve normalized to dose (AUC/dose) $1.06(0.88-1.27)$ and $1.14(0.76-1.71)$; and $F_{\mathrm{U}}$ 0.99 (0.94-1.04) and 0.97 (0.87-1.09), respectively. Estimated slopes of linear regression of log parameters versus $\log$ CrCL (renal impairment) were: CL/BSA $0.06(-0.15$ to 0.28 ); AUC/dose -0.07 ( -0.30 to 0.16 ); and $F_{\mathrm{U}} 0.02$ ( -0.05 to 0.08$)$. Cabazitaxel safety profile was consistent with previous reports.

Conclusions Renal impairment had no clinically meaningful effect on cabazitaxel pharmacokinetics.

Keywords Cabazitaxel - Renal impairment . Pharmacokinetics · Phase I · Advanced solid tumors

5 Department of Medical Oncology, Fondazione IRCCS National Cancer Institute of Milan, Milan, Italy

6 Early Phase Clinical Trials Team, Department of Oncology, University of Cambridge, Cambridge, UK

7 Erasmus MC Cancer Institute, Erasmus University Medical Center, Rotterdam, The Netherlands

8 Sanofi, Chilly-Mazarin, France

9 Sanofi, Bridgewater, NJ, USA 


\section{Introduction}

Impaired renal function is often observed in patients with solid tumors, with 40-60\% reporting abnormal or impaired renal function across several studies [1-8]. Renal impairment can be the result of advanced age or chronic comorbidities, such as diabetes, hypertension or kidney disease, or can be caused by the cancer itself or the cancer treatment received [1, 8-13]. Several cancer therapies are nephrotoxic, including some chemotherapies, targeted agents, analgesics, radiopharmaceuticals, radiology contrast agents and antiresorptive agents [1]. For some anticancer therapies, including cisplatin, renal impairment is a contraindication; for example, $40-50 \%$ of patients with advanced bladder cancer cannot receive cisplatin because of its associated nephrotoxicity [8]. Renal impairment in patients receiving treatment for cancer is often associated with diminished drug metabolism and metabolite excretion, along with changes in absorption, renal and hepatic metabolism, and plasma protein binding and distribution, which all lead to altered pharmacokinetics (PK) of the drug received [11-13].

In the Renal Insufficiency and Anticancer Medications (IRMA) study, of 4684 patients with solid tumors (breast, colorectal cancer, lung, ovarian and prostate cancer), 57 and $53 \%$ of patients had renal impairment, depending on the type of formula used to calculate renal function, and of the 222 patients with prostate cancer, 63 and $56 \%$ of patients presented with renal impairment $[2,5]$. Cabazitaxel is a second-generation taxane that has demonstrated efficacy in the second-line treatment of castration-resistant prostate cancer after docetaxel-based treatment [14]. Although renal elimination of cabazitaxel is minimal (approximately $2.3 \%$ is excreted renally as unchanged drug) $[10,15,16]$, previous studies of cabazitaxel in patients with solid tumors have generally excluded patients with renal impairment $[14,17]$. Some data on the PK of cabazitaxel in patients with renal impairment are available from a population PK analysis of phase I-III trials [16]. Of 170 patients included in this analysis, 59 patients had mild renal impairment, 14 patients had moderate renal impairment, and one patient had severe renal impairment. As expected with the minimal renal elimination of cabazitaxel, the population PK analysis did not identify renal impairment as a significant covariate influencing cabazitaxel PK.

The present study was performed to confirm the results of the previous population PK analysis [16] and to provide guidance regarding cabazitaxel dosing in patients with renal impairment. This study assessed the PK and safety of cabazitaxel in patients with advanced solid tumors and moderate or severe renal impairment compared with normal renal function. The primary objective of this study was to assess the effect of moderate and severe renal impairment on the PK of cabazitaxel. The secondary objective was to assess the safety of cabazitaxel in patients with moderate and severe renal impairment.

\section{Materials and methods}

\section{Study design}

This was an open-label, multicenter, phase I study (NCT01527929) in patients with advanced solid tumors and varying degrees of stable, chronic renal impairment or normal renal function. Patients were enrolled into one of three cohorts at seven institutions across five countries. Renal function cohorts were defined by creatinine clearance $(\mathrm{CrCL})$, calculated using the Chronic Kidney Disease Epidemiology Collaboration equation (CKD-EPI) formula [18-20]. Patients were enrolled into Cohort A: normal renal function $\left(\mathrm{CrCL}>80 \mathrm{~mL} / \mathrm{min} / 1.73 \mathrm{~m}^{2}\right)$, Cohort B: moderate renal impairment $\left(\mathrm{CrCL} \geq 30\right.$ to $<50 \mathrm{~mL} / \mathrm{min} / 1.73 \mathrm{~m}^{2}$ ) or Cohort C: severe renal impairment $(\mathrm{CrCL}<30 \mathrm{~mL} /$ $\min / 1.73 \mathrm{~m}^{2}$ ).

Cabazitaxel was provided as a sterile non-pyrogenic solution in $60-\mathrm{mg}$ vials, diluted into a premix solution prior to use and administered within $8 \mathrm{~h}$ of preparation. All patients received 1-h intravenous (IV) infusions of cabazitaxel on Day 1 of 3-weekly cycles until unacceptable toxicity, disease progression, withdrawal of consent, investigator decision or study cutoff. Cabazitaxel starting doses were based on the renal function stratification. Based on available PK data for patients with normal renal function and moderate renal impairment, no significant changes of cabazitaxel PK were expected in these patients. Therefore, the approved cabazitaxel dose of $25 \mathrm{mg} / \mathrm{m}^{2}$ was administered to patients with normal renal function (Cohort A) or moderate renal impairment (Cohort B). For patients with severe renal impairment, cabazitaxel starting dose was $20 \mathrm{mg} / \mathrm{m}^{2}$, escalated to $25 \mathrm{mg} / \mathrm{m}^{2}$ at later cycles if no doselimiting toxicities (DLTs) were observed during Cycle 1. For Cohort C, PK assessment was carried out at the two dose levels for patients who received $25 \mathrm{mg} / \mathrm{m}^{2}$ at later cycles. The $20 \mathrm{mg} / \mathrm{m}^{2}$ starting dose was based on a possible increase in the free fraction of cabazitaxel in patients with severe renal impairment due to its high plasma protein binding (91.6\%, mostly to albumin and lipoproteins) and the frequency of hypoalbuminemia in such patients. DLTs were defined as the following cabazitaxel-related adverse events (AEs, as assessed by the investigator): grade 2 vomiting and/or diarrhea; grade 3-4 non-hematologic AE (excluding grade 3 fatigue and transaminase or bilirubin elevation that returned to baseline prior to next treatment cycle); hematologic toxicity, defined as neutropenic infection, febrile neutropenia (fever of unknown 
origin without documented infection, with grade 3-4 neutropenia), grade 4 neutropenia lasting $>7$ days, or grade 3-4 thrombocytopenia. Toxicity and AEs were graded and recorded according to National Cancer Institute Common Terminology Criteria for AEs (NCI CTCAE) v4.03 [21]. Granulocyte-colony stimulating factor (G-CSF) was allowed with therapeutic or prophylactic intent and left to the investigator's judgement.

\section{Patient population}

Patients had a diagnosis of a histologically or cytologically proven non-hematologic malignancy that was refractory to standard therapy or for which no standard therapy was available, and for which cabazitaxel was judged to be an adequate treatment option by the investigator. Eligible patients were $\geq 18$ years of age with a life expectancy of $>3$ months, an Eastern Cooperative Oncology Group (ECOG) performance status (PS) of 0,1 or 2 , stable renal function (defined as CrCL within a range of $\pm 10 \%$ during a 3-month period with $\geq 3$ measurements performed), and adequate liver and bone marrow function (defined as absolute neutrophil count $\geq 1.5 \times 10^{9} / \mathrm{L}$, platelets $\geq 100 \times 10^{9} / \mathrm{L}$, total bilirubin $\leq 1.0 \times$ institution upper limit of normality [ULN], transaminases $\leq 2.5 \times$ ULN, and alkaline phosphatase $\leq 2.5 \times \mathrm{ULN})$. Patients must have completed prior anticancer therapy $\geq 4$ weeks before study entry. Key exclusion criteria included neurotoxicity of grade $\geq 2$, acute renal failure or dialysis that would be required during the study, history of hypersensitivity to docetaxel or polysorbate 80 , known brain metastases, and any treatments known to strongly induce CYP3A isoenzymes or to strongly inhibit CYP3A4 activity within 2 weeks before or during the test period for PK sampling. The institutional review board at each participating institution approved the protocol. Written informed consent was obtained from all patients. The study was conducted in accordance with the ethical principles stated in the Declaration of Helsinki and good clinical practice.

\section{Baseline and on study assessments}

Medical histories were recorded at baseline and assessment of vital signs, physical examinations, ECOG PS, and electrocardiograms were performed at baseline prior to cabazitaxel administration, during study treatment as required and $\geq 30$ days after the last administration of study treatment. All signs and symptoms observed from the time of informed consent were recorded as AEs. All AEs were recorded until 30 days after last administration of study treatment. After this follow-up period, only new or ongoing treatment-related AEs were recorded, except for ongoing serious AEs, which were assessed until resolution or stabilization, regardless of relationship to study treatment. Weekly laboratory evaluations were performed including cell blood counts with differentials, and analysis of coagulation, liver function, plasma electrolytes, glucose, albumin, total proteins, blood urea nitrogen, creatinine and urinalysis. An eye examination was performed at baseline and end of study. CrCL was determined using the CKD-EPI formula and if $\mathrm{CrCL}$ decreased by $50 \%$ from baseline during the study, or if dialysis was required, treatment was discontinued. The maximum dose delay allowed, due to acute toxicity, was 2 weeks. If the treatment gap was longer than 2 weeks, the patient was discontinued from study treatment. If the dose was reduced due to toxicity, then it was not re-escalated. Up to a maximum of two dose reductions were allowed per patient. Radiologic studies for disease assessment were conducted pretreatment and according to the site practice. Tumor response was assessed according to the Response Evaluation Criteria in Solid Tumors (RECIST 1.1).

\section{Pharmacokinetic sampling and bioanalytical methodology}

Heparinized blood samples were collected from all patients for cabazitaxel concentration measurement at Cycle 1 (and Cycle 2, or Cycle 3 for one patient, following dose escalation in Cohort C) before start of infusion, $5 \mathrm{~min}$ before the end of infusion and then 5, 15 and $30 \mathrm{~min}$, and 1, 2, 3, 5 and $8 \mathrm{~h}$ post-infusion, and at approximately 24 (Day 2), 48 (Day 3), 72 (Day 4), 120 (Day 6), 168 (Day 8) and 216 (Day 10) $\mathrm{h}$ after the end of infusion. The timing of treatment administration and timing of sampling were precisely recorded for each patient. Total cabazitaxel concentrations in the plasma were determined using a validated liquid chromatography with tandem mass spectrometry method (LC-MS/MS) with a lower limit of quantification (LLOQ) of $1 \mathrm{ng} / \mathrm{mL}$ [22, 23]. In addition, blood samples were collected to determine the free, unbound fraction of cabazitaxel in all patients at Cycle 1 before start of infusion, $5 \mathrm{~min}$ before the end of infusion, and 3 and $24 \mathrm{~h}$ after end of infusion. Free cabazitaxel concentrations were determined after equilibrium dialysis in buffer using a validated LC-MS/MS method with a LLOQ of $0.1 \mathrm{ng} / \mathrm{mL}$.

\section{Pharmacokinetic endpoints and analysis}

The primary PK endpoints were area under the plasma concentration versus time curve (AUC) and cabazitaxel clearance (CL). Secondary PK endpoints included observed maximum plasma concentration $\left(C_{\max }\right)$, volume of distribution at steady state $\left(V_{\mathrm{ss}}\right)$ and elimination half-life $\left(t_{1 / 2 \times 3}\right) . V_{\mathrm{ss}}$ and CL normalized by body surface area (BSA; $V_{\mathrm{ss}} / \mathrm{BSA}$ and $\mathrm{CL} / \mathrm{BSA}$ ) were also calculated. Total plasma concentrations 
of cabazitaxel and relative actual time values (as well as actual dose) were used to calculate the PK parameters using non-compartmental analysis (for $C_{\max }$ ) and individual modeling using a three-compartment open model with first-order elimination (for CL, AUC, $V_{\mathrm{ss}}$ and $t_{1 / 2 \times 3}$ ). The calculation of PK parameters was performed using validated softwares (PKDMS version 2 running with WinNonlin Professional, version 5.2.1, Pharsight and WinNonlin Professional, version 6.3, Phoenix, Pharsight), as described previously [24, 25].

\section{Statistical analysis}

Sample size for this study was based on empirical considerations and on the experiences in previous population studies; no formal sample size calculation was performed. A total of 24 to 27 patients were expected to be enrolled (at least 8 patients enrolled and evaluable for final PK evaluation in each cohort). One patient with a major deviation (missing PK sample at a critical time point) was excluded from the PK analysis. Statistical analysis evaluated the effect of population group on cabazitaxel PK parameters by modeling the relationship between measures of renal function (CrCL) and the PK parameters with a regression model as recommended by the United States Food and Drug Administration (FDA) and European Medicines Agency (EMA) [12, 13]. Log-transformed PK parameters were analyzed using a linear regression model with the independent variable being log-transformed CrCL at screening. Log-transformed BSA was a covariate in the models except in models using BSA normalized parameters. The effect of renal impairment on cabazitaxel PK parameters was analyzed using a linear fixed effects model. Geometric mean estimates were determined using $\log \mathrm{CrCL}$ values corresponding to the mean boundaries of the $\mathrm{CrCL}$ interval covering the patient cohorts with moderate renal impairment $\left(40 \mathrm{~mL} / \mathrm{min} / 1.73 \mathrm{~m}^{2}\right)$ and severe renal impairment $(15 \mathrm{~mL} /$ $\min / 1.73 \mathrm{~m}^{2}$ ), along with a value representing the normal population and defined as the control $\left(90 \mathrm{~mL} / \mathrm{min} / 1.73 \mathrm{~m}^{2}\right)$. Using the regression model parameter estimates, point estimates for PK parameters corresponding to CrCL of 90,40 and $15 \mathrm{~mL} /$ $\min / 1.73 \mathrm{~m}^{2}$ were calculated after converting these values to the log scale. Geometric mean estimates were computed, and estimates for the geometric mean ratio of each population group ( 40 and $15 \mathrm{~mL} / \mathrm{min} / 1.73 \mathrm{~m}^{2}$ ) versus the control population group $\left(90 \mathrm{~mL} / \mathrm{min} / 1.73 \mathrm{~m}^{2}\right)$ were calculated. A similar analysis was performed for the models using BSA normalized parameters except log BSA was not used. Cabazitaxel unbound fraction was measured longitudinally in each patient. To estimate cabazitaxel unbound fraction, a linear mixed model was used with $\log$ BSA, $\log \mathrm{CrCL}$ at screening and time as fixed effects, and random intercept and time slope as random effects.

\section{Results}

\section{Patient characteristics}

Of 32 patients screened, 25 were enrolled between April 2012 and November 2013 including eight in Cohort A (normal renal function), eight in Cohort B (moderate renal impairment) and nine in Cohort $\mathrm{C}$ (severe renal impairment; Table 1). No patients failed screening due to renal function. All 25 patients were Caucasian and there was a balanced male/female distribution across all cohorts (Table 1). Baseline liver function appeared consistent across the cohorts with similar rates of hypoalbuminemia (Cohort A: 0; Cohort B: 1/8; Cohort C: 1/9), increased alkaline phosphatase levels (Cohort A: 4/8; Cohort B: 3/8; Cohort C: 2/9), and increased aspartate aminotransferase levels (Cohort A: 0; Cohorts B: 1/8; Cohort C: 1/9), reported at baseline for the three cohorts. Most patients $(60 \%)$ had received $\geq 3$ prior anticancer therapies, prior surgery had been performed in $80 \%$, and prior radiation therapy had been administered to $48 \%$ of patients. Median CrCL at baseline was $96.8 \mathrm{~mL} / \mathrm{min}$ in patients with normal renal function (Cohort A), $44.6 \mathrm{~mL} / \mathrm{min}$ in patients with moderate renal impairment (Cohort B) and $25.2 \mathrm{~mL} /$ min in patients with severe renal impairment (Cohort $\mathrm{C}$ ). The CrCL remained stable in all patients during the study period (Fig. 1).

\section{Treatment characteristics}

A total of 140 cycles of cabazitaxel were delivered to 25 patients. The median number of cabazitaxel cycles administered was three (range 1-20; Table 1). The median number of cabazitaxel cycles was similar for patients with varying degrees of renal function, and median relative dose intensity was $>90 \%$ in all cohorts. The median duration of study treatment was also similar between cohorts (Table 1). More than one cycle of cabazitaxel $25 \mathrm{mg} / \mathrm{m}^{2}$ was received by all eight patients with normal renal function (Cohort A) and seven of eight patients with moderate renal impairment (Cohort B). The remaining patient in Cohort $\mathrm{B}$ received cabazitaxel $25 \mathrm{mg} / \mathrm{m}^{2}$ in Cycle 1 only and then received $20 \mathrm{mg} / \mathrm{m}^{2}$ in Cycle 2, following dose reduction due to febrile neutropenia. Of the nine patients with severe renal impairment in Cohort $\mathrm{C}$ who received a cabazitaxel starting dose of $20 \mathrm{mg} / \mathrm{m}^{2}$, four patients had a dose escalation to $25 \mathrm{mg} /$ $\mathrm{m}^{2}$ (three patients at Cycle 2 and one patient at Cycle 3). The remaining five patients did not receive dose escalations because of DLTs $(n=3)$ and investigator decision $(n=2)$. In Cohort C, one DLT of grade 3 febrile 
Table 1 Baseline patient characteristics and treatment characteristics

\begin{tabular}{llllll}
$\begin{array}{l}\text { Cohort A } \\
\text { (normal renal }\end{array}$ & $\begin{array}{l}\text { Cohort B } \\
\text { (moderate renal }\end{array}$ & \multicolumn{2}{l}{ Cohort C (severe renal impairment) } & All patients \\
\cline { 2 - 4 } function) & impairment) & All patients & Received only & Escalated to & \\
$25 \mathrm{mg} / \mathrm{m}^{2}$ & $25 \mathrm{mg} / \mathrm{m}^{2}$ & $($ starting dose & $20 \mathrm{mg} / \mathrm{m}^{2}$ & $25 \mathrm{mg} / \mathrm{m}^{2}$ & \\
$n=8$ & $n=8$ & $\left.20 \mathrm{mg} / \mathrm{m}^{2}\right)$ & $n=5^{\mathrm{a}}$ & $n=4$
\end{tabular}

Patient characteristics

Male/female, $n \quad 2 / 6$

Age, years, median 58.5 (38-72)

$\begin{array}{lllll}4 / 4 & 5 / 4 & 3 / 2 & 2 / 2 & 11 / 14 \\ 65.0(42-77) & 66.0(44-77) & 69.0(61-77) & 63.0(44-75) & 62.0(38-77)\end{array}$

(range)

ECOG performance status, $n$

$\begin{array}{lllllll}0 & 5 & 1 & 2 & 2 & 0 & 8 \\ 1 & 3 & 6 & 7 & 3 & 4 & 16 \\ 2 & 0 & 1 & 0 & 0 & 0 & 1 \\ \text { Months since } & 51.8(6.6-113.4) & 37.2(8.6-460.7) & 44.0(15.5-154.7) & 84.6(15.5-154.7) & 41.0(25.4-55.6) & 44.0(6.6-460.7)\end{array}$

diagnosis, median

(range)

Primary tumor site, $n$

\begin{tabular}{|c|c|c|}
\hline Breast & 2 & 0 \\
\hline Cervix & 0 & 2 \\
\hline Colon/rectum & 3 & 0 \\
\hline Esophagus & 0 & 2 \\
\hline Ovary & 1 & 1 \\
\hline Pancreas & 1 & 1 \\
\hline Prostate & 0 & 0 \\
\hline Other $^{\mathrm{b}}$ & 1 & 2 \\
\hline
\end{tabular}

Tumor histology, $n$

$\begin{array}{ll}\text { Adenocarcinoma } & 6 \\ \text { Carcinoma } & 1 \\ \text { Sarcoma } & 0 \\ \text { Other } & 1\end{array}$

3
4
1
0

Extent of disease at study entry, $n$

$\begin{array}{ll}\text { Locally advanced } & 0 \\ \text { Metastatic } & 8\end{array}$

$0 \quad 1$

Metastatic

8

8

Prior anticancer regimens, $n$

1
2
$\geq 3$

Prior taxane 4

therapy, $n$

Creatinine clear-

$$
\begin{aligned}
& 96.78 \\
& (93.3-101.1)
\end{aligned}
$$

\section{1}

3

4

4

nce, $\mathrm{mL} / \mathrm{min}$,

44.60

(38.8-49.9)

25.24

$(8.0-29.0)$

15.06

$$
(8.0-25.2)
$$

27.40

(26.5-29.0)

4.39

Treatment characteristics

Cabazitaxel cycles, $n$

\begin{tabular}{lllllll} 
Total & 45.0 & 41.0 & 54.0 & 39.0 & 15.0 & 140.0 \\
$\begin{array}{l}\text { Median per } \\
\text { patient (range) }\end{array}$ & $5.0(2-13)$ & $3.0(1-15)$ & $5.0(1-20)$ & $6.0(1-20)$ & $4.0(2-5)$ & $3.0(1-20)$ \\
$\begin{array}{l}\text { Relative dose } \\
\text { intensity, } \mathrm{mg} / \mathrm{m}^{2} /\end{array}$ & $91.6(79.2-99.8)$ & $99.7(70.2-101.1)$ & $99.0(88.8-99.9)$ & $99.3(92.3-99.9)$ & $98.6(88.8-99.9)$ & $98.3(70.2-101.1)$ \\
$\begin{array}{l}\text { week, median } \\
\text { (range) }\end{array}$ & & & & & & \\
\hline
\end{tabular}


Table 1 continued

\begin{tabular}{|c|c|c|c|c|c|c|}
\hline & \multirow{2}{*}{$\begin{array}{l}\text { Cohort A } \\
\text { (normal renal } \\
\text { function) } \\
25 \mathrm{mg} / \mathrm{m}^{2} \\
n=8\end{array}$} & \multirow{2}{*}{$\begin{array}{l}\text { Cohort B } \\
\text { (moderate renal } \\
\text { impairment) } \\
25 \mathrm{mg} / \mathrm{m}^{2} \\
n=8\end{array}$} & \multicolumn{3}{|c|}{ Cohort C (severe renal impairment) } & \multirow{2}{*}{$\begin{array}{l}\text { All patients } \\
N=25\end{array}$} \\
\hline & & & $\begin{array}{l}\text { All patients } \\
\text { (starting dose } \\
20 \mathrm{mg} / \mathrm{m}^{2} \text { ) } \\
n=9\end{array}$ & $\begin{array}{l}\text { Received only } \\
20 \mathrm{mg} / \mathrm{m}^{2} \\
n=5^{\mathrm{a}}\end{array}$ & $\begin{array}{l}\text { Escalated to } \\
25 \mathrm{mg} / \mathrm{m}^{2} \\
n=4\end{array}$ & \\
\hline $\begin{array}{l}\text { Duration of study } \\
\text { treatment, weeks, } \\
\text { median (range) }\end{array}$ & $15.1(6.0-46.0)$ & $9.0(3.0-52.1)$ & $15.1(3.0-65.3)$ & $18.0(3.0-65.3)$ & $12.1(6.7-15.3)$ & $11.0(3.0-65.3)$ \\
\hline $\begin{array}{l}\text { Discontinued treat- } \\
\text { ment, } n(\%)\end{array}$ & $8(100)$ & $8(100)$ & $9(100)$ & $5(100)$ & $4(100)$ & $25(100)$ \\
\hline Adverse event & 0 & $2(25.0)$ & $1(11.1)$ & $1(20.0)$ & 0 & $3(12.0)$ \\
\hline $\begin{array}{l}\text { Poor compliance } \\
\text { to protocol }\end{array}$ & 0 & 0 & 0 & 0 & 0 & 0 \\
\hline $\begin{array}{l}\text { Disease progres- } \\
\text { sion }\end{array}$ & $7(87.5)$ & $4(50.0)$ & $4(44.4)$ & 0 & $4(100)$ & $15(60.0)$ \\
\hline Lost to follow-up & 0 & 0 & 0 & 0 & 0 & 0 \\
\hline Patient request & 0 & $1(12.5)$ & $1(11.1)$ & $1(20.0)$ & 0 & $2(8.0)$ \\
\hline Other reason & $1(12.5)$ & $1(12.5)$ & $3(33.3)$ & $3(60.0)$ & 0 & $5(20.0)$ \\
\hline
\end{tabular}

${ }^{a}$ In Cohort $\mathrm{C}$, one patient had a cabazitaxel dose reduction to $15 \mathrm{mg} / \mathrm{m}^{2}$ at Cycle 2; this patient received a $20 \mathrm{mg} / \mathrm{m}^{2}$ dose at Cycle 1 and was therefore included in the PK population and assessed at Cycle 1

${ }^{b}$ One patient each with the following primary tumor sites: skin (Cohort A), adrenal gland (Cohort B), lung (Cohort B), bladder (Cohort C, $20 \mathrm{mg} / \mathrm{m}^{2}$ ), muscle/soft tissue (Cohort C, $20 \mathrm{mg} / \mathrm{m}^{2}$ ), peritoneum (Cohort C, $20 \mathrm{mg} / \mathrm{m}^{2}$ ) and uterus (Cohort C, $25 \mathrm{mg} / \mathrm{m}^{2}$ )

ECOG Eastern Cooperative Oncology Group

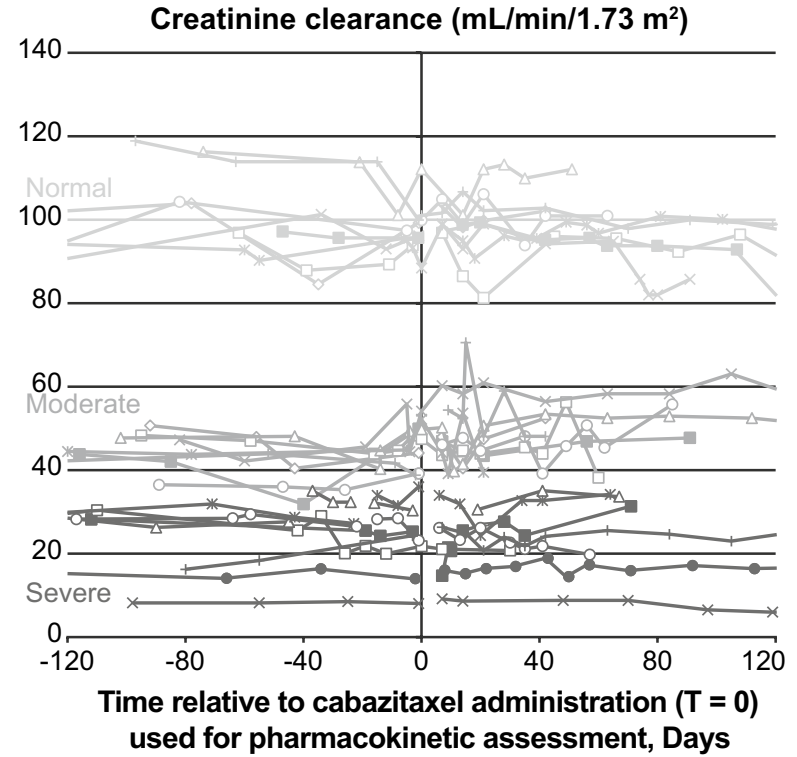

Fig. 1 Creatinine clearance levels observed during the study period; an example observation window of 120 days before to 120 days after cabazitaxel administration and pharmacokinetic assessment is presented

neutropenia led to dose reduction to $15 \mathrm{mg} / \mathrm{m}^{2}$ at Cycle 2 . No patient received two reductions of cabazitaxel dose, and no patient had dose interruptions.

\section{Pharmacokinetics}

Cabazitaxel PK data were obtained from 25 treated patients and 24 were eligible for PK analysis (eight per cohort). One patient (Cohort C) was excluded due to protocol deviation. PK parameters obtained using non-compartmental analysis and three-compartmental analysis (individual modeling) are shown in Table 2. For patients with moderate or severe renal impairment (versus patients with normal renal function), there appeared to be no associations between CL/BSA or AUC normalized to dose (AUC/dose), and degree of renal impairment. Mean CL/BSA observed was similar across all patients with normal renal function $\left(33.5 \mathrm{~L} / \mathrm{h} / \mathrm{m}^{2}\right.$; geometric mean $\left.32.5 \mathrm{~L} / \mathrm{h} / \mathrm{m}^{2}\right)$, moderate renal impairment $(28.9 \mathrm{~L} / \mathrm{h} /$ $\mathrm{m}^{2}$; geometric mean $26.5 \mathrm{~L} / \mathrm{h} / \mathrm{m}^{2}$ ) and severe renal impairment $\left(29.6 \mathrm{~L} / \mathrm{h} / \mathrm{m}^{2}\right.$ for patients receiving 25 and $20 \mathrm{mg} / \mathrm{m}^{2}$ combined; geometric mean $27.0 \mathrm{~L} / \mathrm{h} / \mathrm{m}^{2}$ ). The effect of renal impairment on cabazitaxel PK parameters was evaluated in patients with moderate and severe renal impairment in comparison with patients with normal renal function using a regression model of patient PK parameters from the PK population using $\mathrm{CrCL}$ values obtained at screening. The primary linear regression of log-transformed parameters (AUC/dose and CL/BSA) versus log-transformed CrCL is shown in Fig. 2. Estimated slopes of linear regression for $\log \mathrm{PK}$ parameters versus $\log \mathrm{CrCL}$ were $0.06(90 \% \mathrm{CI}$ $-0.15,0.28)$ for CL/BSA and $-0.07(90 \% \mathrm{CI}-0.30,0.16)$ 
Table 2 Pharmacokinetic parameters

\begin{tabular}{|c|c|c|c|c|}
\hline \multirow[t]{2}{*}{ Parameter, mean $\pm \mathrm{SD}$ (geometric mean) $[\mathrm{CV} \%]$} & \multirow{2}{*}{$\begin{array}{l}\text { Cohort A } \\
\text { (normal renal function) } \\
25 \mathrm{mg} / \mathrm{m}^{2} \\
n=8\end{array}$} & \multirow{2}{*}{$\begin{array}{l}\text { Cohort B } \\
\text { (moderate renal impairment) } \\
25 \mathrm{mg} / \mathrm{m}^{2} \\
n=8\end{array}$} & \multicolumn{2}{|c|}{$\begin{array}{l}\text { Cohort C } \\
\text { (severe renal impairment) }\end{array}$} \\
\hline & & & $\begin{array}{l}20 \mathrm{mg} / \mathrm{m}^{2} \\
n=4^{\mathrm{a}}\end{array}$ & $\begin{array}{l}25 \mathrm{mg} / \mathrm{m}^{2} \\
n=4^{\mathrm{b}}\end{array}$ \\
\hline \multicolumn{5}{|l|}{ Non-compartmental analysis } \\
\hline$C_{\max }, \mathrm{ng} / \mathrm{mL}$ & $\begin{array}{l}161 \pm 57.0 \\
(152)[35]\end{array}$ & $\begin{array}{l}241 \pm 207^{c} \\
(193)[86]\end{array}$ & $\begin{array}{l}135 \pm 45.7 \\
(130)[34]\end{array}$ & $\begin{array}{l}244 \pm 150 \\
(215)[62]\end{array}$ \\
\hline \multicolumn{5}{|l|}{ Individual modeling/three-compartmental analysis } \\
\hline AUC, $n g * h / m L$ & $\begin{array}{l}787 \pm 177 \\
(766)[23]\end{array}$ & $\begin{array}{l}1070 \pm 733 \\
(938)[68]\end{array}$ & $\begin{array}{l}928 \pm 475 \\
(829)[51]\end{array}$ & $\begin{array}{l}857 \pm 263 \\
(823)[31]\end{array}$ \\
\hline $\mathrm{CL}, \mathrm{L} / \mathrm{h}$ & $\begin{array}{l}58.9 \pm 14.7 \\
(57.5)[25]\end{array}$ & $\begin{array}{l}54.1 \pm 21.9 \\
(49.1)[41]\end{array}$ & $\begin{array}{l}51.8 \pm 34.4 \\
(44.8)[66]\end{array}$ & $\begin{array}{l}63.0 \pm 30.5 \\
(58.1)[48]\end{array}$ \\
\hline$V_{\mathrm{ss}}, \mathrm{L}$ & $\begin{array}{l}7730 \pm 3280 \\
(7160)[42]\end{array}$ & $\begin{array}{l}6730 \pm 2970 \\
(6170)[44]\end{array}$ & $\begin{array}{l}5810 \pm 1360 \\
(5690)[23]\end{array}$ & $\begin{array}{l}6470 \pm 3790 \\
(5680)[59]\end{array}$ \\
\hline $\mathrm{CL} / \mathrm{BSA}, \mathrm{L} / \mathrm{h} / \mathrm{m}^{2}$ & $\begin{array}{l}33.5 \pm 9.76 \\
(32.5)[29]\end{array}$ & $\begin{array}{l}28.9 \pm 10.7 \\
(26.5)[37]\end{array}$ & $\begin{array}{l}27.5 \pm 17.1 \\
(24.1)[62]\end{array}$ & $\begin{array}{l}31.7 \pm 11.4 \\
(30.3)[36]\end{array}$ \\
\hline$V_{\mathrm{ss}} / \mathrm{BSA}, \mathrm{L} / \mathrm{m}^{2}$ & $\begin{array}{l}4230 \pm 1360 \\
(4040)[32]\end{array}$ & $\begin{array}{l}3580 \pm 1480 \\
(3320)[41]\end{array}$ & $\begin{array}{l}3130 \pm 730 \\
(3060)[23]\end{array}$ & $\begin{array}{l}3380 \pm 1920 \\
(2970)[57]\end{array}$ \\
\hline$t_{1 / 2 \gamma 3}, \mathrm{~h}$ & $\begin{array}{l}122 \pm 43.8 \\
(116)[36]\end{array}$ & $\begin{array}{l}143 \pm 102 \\
(124)[71]\end{array}$ & $\begin{array}{l}133 \pm 84.4 \\
(113)[63]\end{array}$ & $\begin{array}{l}115 \pm 49.8 \\
(103)[43]\end{array}$ \\
\hline
\end{tabular}

a $n=4$; three patients were not included in the statistical analysis for Cycle $1\left(20 \mathrm{mg} / \mathrm{m}^{2}\right)$ because they were analyzed at Cycle $2\left(25 \mathrm{mg} / \mathrm{m}^{2}\right)$

b $n=4$; one patient was excluded from statistical analyses because the cabazitaxel dose was decreased to $15 \mathrm{mg} / \mathrm{m}^{2}$

${ }^{c} n=7$; one patient was excluded from the calculation of summary statistics because of a sampling time deviation at the end of infusion $A U C$ Area under the plasma concentration-time curve, $C L$ clearance, $C L / B S A$ clearance normalized to body surface area, $C_{\text {max }}$ maximum plasma concentration, $C V$ coefficient of variation, $S D$ standard deviation, $t_{1 / 2 \gamma 3}$ elimination half-life, $V_{s s}$ volume of distribution at steady state, $V_{s s} / B S A$ volume of distribution at steady state normalized to body surface area
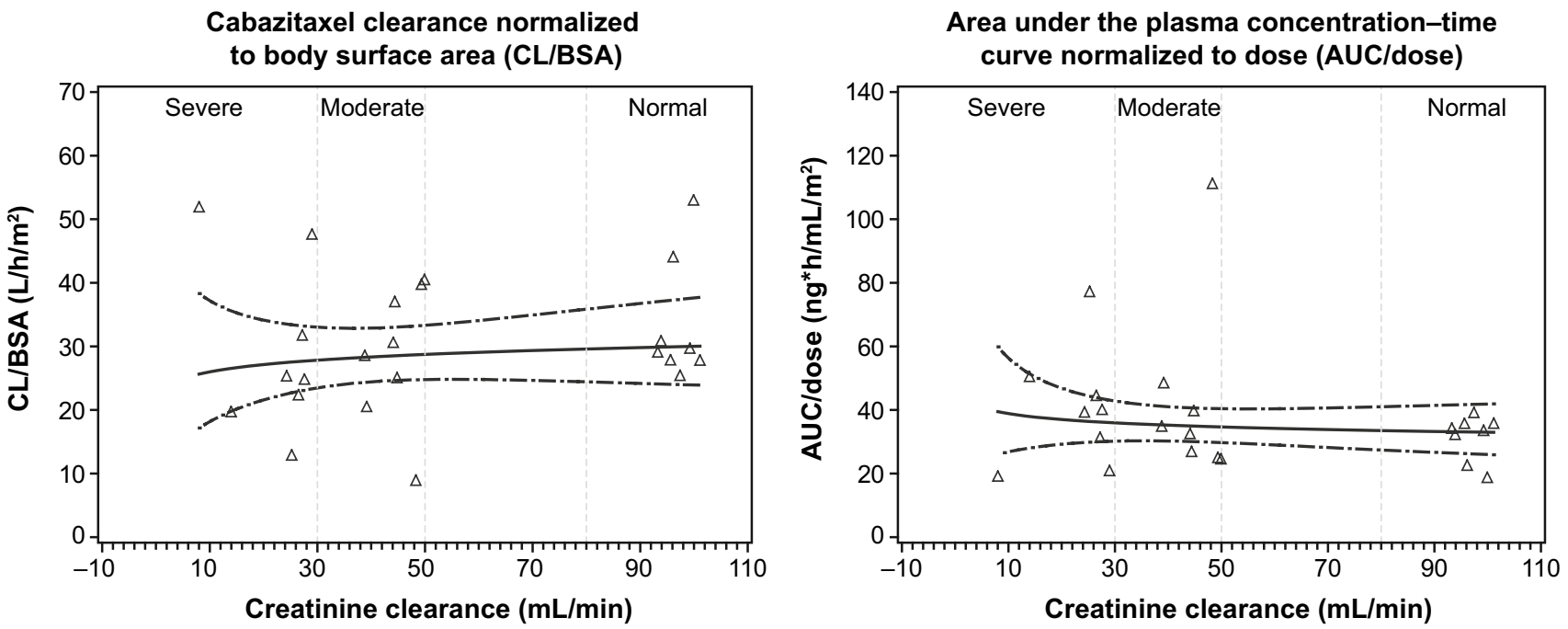

$\triangle$ Individual values $\quad$ Linear regression $\quad-\quad-90 \%$ confidence interval Vertical lines represent Cohort boundaries

Fig. 2 Estimated slope of linear regression for log pharmacokinetic parameters versus creatinine clearance

for AUC/dose. For primary PK parameters, linear regression analysis showed no meaningful increase in cabazitaxel dose-normalized exposure (AUC/dose: $p=0.5961$ ) and no meaningful decrease in cabazitaxel CL/BSA $(p=0.6268)$ associated with the decrease in $\mathrm{CrCL}$ (increased renal impairment) within the range of $8.03-101 \mathrm{~mL} / \mathrm{min}$. 
Table 3 Estimated pharmacokinetic parameters for specified levels of renal function (CrCL)

$\begin{array}{lcc}\begin{array}{l}\text { Normal renal function } \\ \left(\text { CrCL } 90 \mathrm{~mL} / \mathrm{min} / 1.73 \mathrm{~m}^{2}\right)^{\mathrm{a}}\end{array} & \begin{array}{l}\text { Moderate renal impairment } \\ \left(\text { CrCL } 40 \mathrm{~mL} / \mathrm{min} / 1.73 \mathrm{~m}^{2}\right)^{\mathrm{a}}\end{array} & \begin{array}{c}\text { Severe renal impairment } \\ \left(\mathrm{CrCL} 15 \mathrm{~mL} / \mathrm{min} / 1.73 \mathrm{~m}^{2}\right)^{\mathrm{a}}\end{array} \\ \text { 29.81 (24.18-36.75) } & 28.34(24.44-32.86) & 26.66(20.15-35.27) \\ 33.23(26.65-41.44) & 35.21(30.24-40.99) & 37.75(28.29-50.39) \\ 3991.24(3305.36-4819.44) & 3345.54(2927.74-3822.96) & 2702.50(2100.18-3477.57) \\ 5.51(5.08-5.96) & 5.44(5.13-5.76) & 5.36(4.95-5.80) \\ - & & 0.89(0.61-1.32) \\ - & 0.95(0.80-1.13) & 1.14(0.76-1.71) \\ - & 1.06(0.88-1.27) & 0.68(0.48-0.96) \\ - & 0.84(0.72-0.98) & 0.97(0.87-1.09)\end{array}$

a Specified $\mathrm{CrCL}$ values correspond to the mean boundaries of the $\mathrm{CrCL}$ interval covering the patient cohorts with moderate renal impairment $\left(40 \mathrm{~mL} / \mathrm{min} / 1.73 \mathrm{~m}^{2}\right)$ and severe renal impairment $\left(15 \mathrm{~mL} / \mathrm{min} / 1.73 \mathrm{~m}^{2}\right)$, versus a value representing the normal population and defined as the control group $\left(90 \mathrm{~mL} / \mathrm{min} / 1.73 \mathrm{~m}^{2}\right)$

${ }^{\mathrm{b}}$ Model is linear regression: $\log (\mathrm{CL} / \mathrm{BSA})=\log (\mathrm{CrCL})+$ Error

${ }^{c}$ Model is linear regression: $\log (\mathrm{AUC} / \mathrm{dose})=\log (\mathrm{CrCL})+\log (\mathrm{BSA})+$ Error

${ }^{\mathrm{d}}$ Model is linear mixed: $\log ($ fraction unbound $)=\log (\mathrm{CrCL})+\log (\mathrm{BSA})+$ Time $+(\mathrm{b} 0+\mathrm{b} 1 \times$ Time $)+$ Error

$A U C /$ dose Area under the plasma concentration-time curve normalized to dose, $C I$ confidence interval, $C L / B S A$ clearance normalized to body surface area, $C r C L$ creatinine clearance, $F_{U}$ unbound fraction

Estimates for the geometric mean ratios of PK parameters for the renal impairment groups (moderate and severe) versus an estimated control group were determined from the linear regression model (Table 3). Log CrCL values corresponding to the mean boundaries of the $\mathrm{CrCL}$ interval covering the patient cohorts with moderate renal impairment $\left(40 \mathrm{~mL} / \mathrm{min} / 1.73 \mathrm{~m}^{2}\right)$ and severe renal impairment $\left(15 \mathrm{~mL} / \mathrm{min} / 1.73 \mathrm{~m}^{2}\right)$ were used, versus a value representing the normal population and defined as the control group $\left(90 \mathrm{~mL} / \mathrm{min} / 1.73 \mathrm{~m}^{2}\right)$. The geometric mean ratio for AUC in patients with severe renal impairment versus normal renal function $(1.14 ; 90 \%$ CI $0.76,1.71)$ indicated no significant impact of renal impairment. For CL/BSA, the geometric mean ratio for patients with severe renal impairment versus patients with normal renal function was 0.89 (90\% CI 0.61, 1.32). The predicted CL/BSA for patients with severe renal impairment or normal renal function was 26.66 and $29.81 \mathrm{~L} / \mathrm{h} / \mathrm{m}^{2}$, respectively, which accounts for a maximal decrease in cabazitaxel clearance of $10.6 \%$ and indicates no meaningful change in CL/BSA with increased renal impairment. Some secondary PK parameters appeared to have trend for association with decreasing renal function; in particular, $V_{\mathrm{ss}} / \mathrm{BSA}$ was approximately $2700 \mathrm{~L} / \mathrm{m}^{2}$ for patients with severe renal impairment versus approximately $4000 \mathrm{~L} / \mathrm{m}^{2}$ for patients with normal renal function. The log of the linear regression slope was $0.22(90 \%$ CI $0.02,0.41)$, indicating that this trend was marginally statistically significant. Results from a sensitivity analysis, where CrCL changes during the time course of the study were taken into account, showed similar findings.

The estimated unbound fraction of cabazitaxel was low and consistent across the different renal function cohorts (5.36-5.51), indicating that renal impairment had no meaningful effect on the cabazitaxel unbound fraction. This was further supported by the primary linear regression analysis and subsequent estimated slope of linear regression (0.02; $90 \%$ CI $-0.05,0.08)$. Unbound drug PK analysis would therefore lead to the same conclusions as for total drug.

\section{Safety}

All patients experienced at least one treatment-emergent AE (TEAE) of any grade. Twenty-three patients $(92 \%)$ experienced a treatment-related TEAE, which was grade $3-4$ in 12 patients $(48 \%)$. A treatment-related serious TEAE occurred in eight patients $(32 \%)$. There were no specific patterns of AEs associated with renal impairment. For the most frequently reported TEAEs, incidence rates were not notably different between patients with different levels of renal function. The most frequent treatment-related grade 3-4 TEAE was febrile neutropenia in six patients $(24 \%)$, including one patient with normal renal function (Cohort A, $12.5 \%$ ), three patients with moderate renal impairment (Cohort B, 37.5\%) and two patients with severe renal impairment (Cohort C, 22.2\%), followed by diarrhea in three patients $(12 \%)$, comprising two patients with moderate renal impairment (Cohort B, 25\%) and one patient with 
Table 4 Summary of treatment-emergent adverse events (TEAEs) and laboratory abnormalities

\begin{tabular}{|c|c|c|c|c|c|c|c|c|c|c|c|c|c|c|}
\hline \multirow[t]{2}{*}{ Patients, $n(\%)$} & \multirow{2}{*}{\multicolumn{4}{|c|}{$\begin{array}{l}\text { Cohort A } \\
\text { (normal renal function) } \\
25 \mathrm{mg} / \mathrm{m}^{2} \\
n=8\end{array}$}} & \multirow{2}{*}{\multicolumn{2}{|c|}{$\begin{array}{l}\text { Cohort B } \\
\text { (moderate renal } \\
\text { impairment) } \\
25 \mathrm{mg} / \mathrm{m}^{2} \\
n=8\end{array}$}} & \multicolumn{7}{|c|}{ Cohort C (severe renal impairment) } & \multirow{2}{*}{$\begin{array}{l}\text { All patients } \\
N=25\end{array}$} \\
\hline & & & & & & & \multicolumn{3}{|c|}{$\begin{array}{l}\text { All patients } \\
\text { (starting dose } 20 \mathrm{mg} / \\
\mathrm{m}^{2} \text { ) } \\
n=9\end{array}$} & \multicolumn{2}{|c|}{$\begin{array}{l}\text { Received only } \\
20 \mathrm{mg} / \mathrm{m}^{2} \\
n=5^{\mathrm{a}}\end{array}$} & \multicolumn{2}{|c|}{$\begin{array}{l}\text { Escalated to } \\
25 \mathrm{mg} / \mathrm{m}^{2} \\
n=4\end{array}$} & \\
\hline \multicolumn{2}{|l|}{$\begin{array}{l}\text { Grade 3-4 TEAEs, } \\
n(\%)\end{array}$} & \multicolumn{3}{|c|}{$6(75.0)$} & \multicolumn{2}{|c|}{$5(62.5)$} & \multicolumn{3}{|c|}{$8(88.9)$} & \multicolumn{2}{|l|}{$5(100)$} & \multicolumn{2}{|l|}{$3(75.0)$} & $19(76.0)$ \\
\hline \multicolumn{15}{|c|}{ Grade 3-4 treatment-related TEAEs, $n(\%)$} \\
\hline Any & & \multicolumn{3}{|c|}{$4(50.0)$} & \multicolumn{2}{|c|}{$3(37.5)$} & \multicolumn{3}{|c|}{$5(55.6)$} & \multicolumn{2}{|l|}{$4(80.0)$} & $1(25.0)$ & \multicolumn{2}{|c|}{$12(48.0)$} \\
\hline Diarrhea & & \multicolumn{3}{|l|}{0} & $2(25$ & & & 1.1) & & $1(20.0)$ & & 0 & & $(12.0)$ \\
\hline Asthenia & & $1(12$. & & & 0 & & 0 & & & 0 & & 0 & & $(4.0)$ \\
\hline Dizziness & & 0 & & & 0 & & & 1.1) & & 0 & & $1(25.0)$ & & $(8.0)$ \\
\hline Fatigue & & 0 & & & $1(12$ & & 0 & & & 0 & & 0 & & $(4.0)$ \\
\hline Abdominal pain & & 0 & & & $1(12$ & & 0 & & & 0 & & 0 & & $(4.0)$ \\
\hline Febrile neutropenia & & $1(12$. & & & $3(37$ & & & $2.2)$ & & $1(20.0)$ & & $1(25.0)$ & & $(24.0)$ \\
\hline Soft tissue infectior & & $1(12$. & & & 0 & & 0 & & & 0 & & 0 & & (4.0) \\
\hline Grade 3-4 hematolo & gic 7 & TEAEs & f any cau & lity, & $n(\%)$ & & & & & & & & & \\
\hline Anemia & & $1(12$. & & & $1(12$ & & & 1.1) & & $1(20.0)$ & & 0 & & $(12.0)$ \\
\hline Leukopenia & & $7(87$. & & & $7(87$ & & & $6.7)$ & & $3(60.0)$ & & $3(75.0)$ & & $(80.0)$ \\
\hline Neutropenia & & $7(87$. & & & $7(87$ & & & 7.8) & & $4(80.0)$ & & $3(75.0)$ & & $(84.0)$ \\
\hline Lymphopenia & & $3(37$. & & & $4(50$ & & & 3.3) & & $2(40.0)$ & & $1(25.0)$ & & $(40.0)$ \\
\hline Grade 3-4 laboratory & $y a b$ & normal & ies of any & ausal & ity, $n$ ( & & & & & & & & & \\
\hline $\begin{array}{l}\text { Alkaline phosphata } \\
\text { increased }\end{array}$ & & $1(12$. & & & 0 & & 0 & & & 0 & & 0 & & (4.0) \\
\hline Hypercalcemia & & $2(25$. & & & 0 & & 0 & & & 0 & & 0 & & $(8.0)$ \\
\hline Creatinine increase & & 0 & & & 0 & & & 4.4) & & $4(80.0)$ & & 0 & & $(16.0)$ \\
\hline Hyperkalemia & & 0 & & & 0 & & & 1.1) & & $1(20.0)$ & & 0 & & (4.0) \\
\hline Hypokalemia & & 0 & & & 0 & & & 1.1) & & 0 & & $1(25.0)$ & & (4.0) \\
\hline Hypermagnesmia & & 0 & & & 0 & & & $2.2)$ & & $1(20.0)$ & & $1(25.0)$ & & (8.0) \\
\hline Blood bilirubin & & $1(12$. & & & 0 & & 0 & & & 0 & & 0 & & $(4.0)$ \\
\hline & $\begin{array}{l}\text { All } \\
\text { gra }\end{array}$ & & $\begin{array}{l}\text { Grade } \\
3-4\end{array}$ & $\begin{array}{l}\text { All } \\
\text { gra }\end{array}$ & & $\begin{array}{l}\text { Grade } \\
3-4\end{array}$ & $\begin{array}{l}\text { All } \\
\text { grades }\end{array}$ & $\begin{array}{l}\text { Grade } \\
3-4\end{array}$ & $\begin{array}{l}\text { All } \\
\text { grades }\end{array}$ & $\begin{array}{l}\text { Grade } \\
3-4\end{array}$ & $\begin{array}{l}\text { All } \\
\text { grades }\end{array}$ & $\begin{array}{l}\text { Grade } \\
3-4\end{array}$ & $\begin{array}{l}\text { All } \\
\text { grades }\end{array}$ & $\begin{array}{l}\text { Grade } \\
3-4\end{array}$ \\
\hline Renal and urinary $\mathrm{TH}$ & $\mathrm{EAE}$ & is of an & causality, & $(\%)$ & & & & & & & & & & \\
\hline $\begin{array}{l}\text { Any renal and } \\
\text { urinary disorder }\end{array}$ & $3(3$ & 37.5) & 0 & $1(1$ & 2.5) & 0 & $1(11.1)$ & 0 & $1(20.0)$ & 0 & 0 & 0 & $5(20.0)$ & 0 \\
\hline Dysuria & $1(1$ & 12.5) & 0 & 0 & & 0 & 0 & 0 & 0 & 0 & 0 & 0 & $1(4.0)$ & 0 \\
\hline Renal colic & $1(1$ & 12.5) & 0 & 0 & & 0 & 0 & 0 & 0 & 0 & 0 & 0 & $1(4.0)$ & 0 \\
\hline $\begin{array}{l}\text { Non-infective } \\
\text { cystitis }\end{array}$ & & 12.5) & 0 & 0 & & 0 & 0 & 0 & 0 & 0 & 0 & 0 & $1(4.0)$ & 0 \\
\hline Hematuria & $1(1$ & 12.5) & 0 & 0 & & 0 & 0 & 0 & 0 & 0 & 0 & 0 & $1(4.0)$ & 0 \\
\hline $\begin{array}{l}\text { Acute renal } \\
\text { failure }\end{array}$ & 0 & & 0 & $1(1$ & 2.5) & 0 & 0 & 0 & 0 & 0 & 0 & 0 & $1(4.0)$ & 0 \\
\hline Urinary retention & 0 & & 0 & 0 & & 0 & $1(11.1$ & 0 & $1(20.0)$ & 0 & 0 & 0 & $1(4.0)$ & 0 \\
\hline Discontinuations due & e to & TEAE & $n(\%)$ & & & & & & & & & & & \\
\hline $\begin{array}{l}\text { Any TEAE lead- } \\
\text { ing to treatment } \\
\text { discontinuation }\end{array}$ & 0 & & 0 & $2(2$ & $5.0)$ & $2(25.0)$ & $1(11.1$ & $1(11.1)$ & $1(20.0)$ & $1(20.0)$ & 0 & 0 & $3(12.0)$ & $3(12.0)$ \\
\hline $\begin{array}{l}\text { Cholecystitis, } \\
\text { infective }\end{array}$ & 0 & & 0 & $1(1$ & 2.5) & $1(12.5)$ & 0 & 0 & 0 & 0 & 0 & 0 & $1(4.0)$ & $1(4.0)$ \\
\hline Colitis, ischemic & 0 & & 0 & 0 & & 0 & $1(11.1$ & $1(11.1)$ & $1(20.0)$ & $1(20.0)$ & 0 & 0 & $1(4.0)$ & $1(4.0)$ \\
\hline
\end{tabular}


Table 4 continued

\begin{tabular}{lllllllllllll}
\hline & All & Grade & All & Grade & All & Grade & All \\
grades & $3-4$ & grades & $3-4$ & grades & $\begin{array}{l}\text { Grade } \\
\text { grad }\end{array}$ & $\begin{array}{l}\text { All } \\
\text { grades }\end{array}$ & $\begin{array}{l}\text { Grade } \\
3-4\end{array}$ & $\begin{array}{l}\text { All } \\
\text { grades }\end{array}$ & $\begin{array}{l}\text { Grade } \\
3-4\end{array}$ \\
\hline Diarrhea & 0 & 0 & $1(12.5)$ & $1(12.5)$ & 0 & 0 & 0 & 0 & 0 & 0 & $1(4.0)$ & $1(4.0)$ \\
Pneumonia & 0 & 0 & 0 & 0 & $1(11.1)$ & 0 & $1(20.0)$ & 0 & 0 & 0 & $1(4.0)$ & 0 \\
\hline
\end{tabular}

${ }^{a}$ In Cohort C, one patient had a cabazitaxel dose reduction to $15 \mathrm{mg} / \mathrm{m}^{2}$ at Cycle 2; this patient received a $20 \mathrm{mg} / \mathrm{m}^{2}$ dose at Cycle 1 and was therefore included in the PK population and assessed at Cycle 1

${ }^{\mathrm{b}}$ Hematoloigc TEAEs based on laboratory abnormalities

severe renal impairment (Cohort C, 11.1\%; Table 4). The most frequent grade 3-4 hematologic TEAE based on laboratory assessments was neutropenia which was reported in 21 patients $(84 \%)$ including seven patients from each cohort of patients (Cohort A, 87.5\%; Cohort B, 87.5\%; Cohort C, $77.8 \%$ ), followed by leukopenia in 20 patients (80\%), comprising seven patients with normal renal function (Cohort A, 87.5\%), seven patients with moderate renal impairment (Cohort B, 87.5\%) and six patients with severe renal impairment (Cohort C, 66.7\%; Table 4). Grade 3-4 laboratory abnormalities, such as isolated electrolyte imbalances, were reported in a small number of patients and are anticipated in this population of advanced cancer patients with renal insufficiency and some with possible paraneoplastic syndromes (Table 4). There was no specific pattern of abnormality detected. Differences among cohorts in the number of patients presenting with creatinine increase were also anticipated and were directly related to their renal function status. No grade 3-4 TEAEs related to renal and urinary toxicity were observed in any patient (a detailed overview of TEAEs is displayed in Table 4).

Patients with severe renal impairment in Cohort $\mathrm{C}$ were assessed for DLTs during Cycle 1 as part of the dose escalation determination. Three patients in Cohort $\mathrm{C}$ experienced a DLT during Cycle 1, including grade 3 febrile neutropenia, grade 3 diarrhea and grade 3 neutropenia.

Three patients $(12 \%)$ discontinued treatment because of a TEAE (Table 4). Of patients with moderate renal impairment (Cohort B), two patients discontinued cabazitaxel because of treatment-related diarrhea $(n=1)$ and a serious $\mathrm{AE}$ (cholecystitis; $n=1$ ) considered unrelated to treatment. Of patients with severe renal impairment (Cohort $\mathrm{C}$ ), one patient receiving cabazitaxel $20 \mathrm{mg} / \mathrm{m}^{2}$ discontinued treatment because of serious AEs (ischemic colitis and pneumonia) considered unrelated to treatment.

\section{Efficacy}

Efficacy assessments were not an objective of this study, but tumor response by RECIST criteria was evaluated per the investigators usual practice. Partial response was seen in two patients (8\%) including one patient in Cohort $\mathrm{A}$ with breast cancer and one patient in Cohort $\mathrm{C}$ with bladder cancer. Stable disease was reported in 11 patients (44\%) and progressive disease in nine patients (36\%). Three patients were not evaluable for tumor response or did not have measurable disease at baseline.

\section{Discussion and conclusions}

Patients with renal or hepatic impairment are generally excluded from phase I clinical trials due to the challenges they present [26], therefore most cancer treatments are approved with limited information on their PK in these patient populations. PK and safety studies in patients with renal impairment may be requested by regulatory authorities at the time of treatment approval, although many studies are conducted post-approval. The primary goal of phase I PK studies in patients with impaired renal function is to determine whether the PK is altered to such an extent that the dosage should be adjusted from the established, approved dose. There are many previous and ongoing PK studies performed in cancer patients [26-32]. For example, oxaliplatin and imatinib PK studies concluded that, even though drug clearance may be decreased and exposure increased, treatments were well tolerated and no dose reduction was necessary in patients with mild-to-moderate renal impairment [27, 28]. For other treatments such as vinflunine, pemetrexed and eribulin, PK studies supported a dose reduction from the approved dose in patients with renal impairment [29, 30, 32].

Since cabazitaxel is only minimally excreted via the kidneys (3.7 with $2.3 \%$ excreted as unchanged drug) [15], it was considered unlikely that renal impairment would influence the PK of cabazitaxel. This article details the results of the first study conducted to assess the safety and PK of cabazitaxel in patients with moderate or severe renal impairment, as this population of patients have been excluded from prior studies of cabazitaxel or minimally represented. In a previous population PK analysis of cabazitaxel, patients with moderate or severe renal impairment accounted for less than $10 \%$ of the patient population (15/170) [16]. The current phase I PK and safety study confirms the findings of the previous PK population analysis that cabazitaxel dose modification is not required 
for patients with moderate or severe renal dysfunction as renal impairment had no meaningful effect on the PK of cabazitaxel. Increasing renal impairment did not result in any meaningful increase in cabazitaxel dose-normalized exposure or decrease in cabazitaxel CL/BSA. Cabazitaxel clearance was similar regardless of renal impairment and was within the range of values observed in previous studies in patients with advanced solid tumors [16, 24, 25]. In two phase I studies, the mean cabazitaxel clearance rates were high $\left(27.3-44.7 \mathrm{~L} / \mathrm{h} / \mathrm{m}^{2}\right)[24,25]$. In the population PK assessment of cabazitaxel in patients with advanced solid tumors from five different studies, including the two phase I studies (total: $n=170$; ranging between $n=13$ and $n=67)$, the mean clearance of cabazitaxel ranged from 12.1 to $34.5 \mathrm{~L} / \mathrm{h} / \mathrm{m}^{2}$ [16], which was lower than those values obtained from the individual modeling $[24,25]$. The population PK analysis allowed for a better estimation of the PK parameters from the phase I studies as the impact of sample times was reduced. Renal impairment also had no meaningful effect on the unbound fraction of cabazitaxel, which is consistent with the high binding of cabazitaxel to total plasma proteins observed ex vivo and in vitro (89$92 \%)[16,25,33]$.

The trends in PK parameters associated with renal function were not considered clearly established for any parameter because of the large variability in parameters that was not well accounted for by the linear regression models, indicating a limitation of the methodology. This was demonstrated by the lack of precision (large confidence intervals) in the estimates of both geometric mean ratios and point parameters in patients with severe renal impairment. In addition, outlier values in different parameters were seen in different patients. Including a cohort of patients with mild renal impairment in this study would have allowed for assessments over a wider range of renal function and provided information for patients with CrCL levels falling into the $\geq 50$ to $\leq 80 \mathrm{~mL} / \mathrm{min} / 1.73 \mathrm{~m}^{2}$ interval, which may have refined the linear regression models. Patients with mild renal impairment were not included because cabazitaxel is minimally excreted by the kidneys, meaning that assessment of cabazitaxel in patients with moderate or severe renal impairment would provide the most clinically relevant information. In our opinion, the findings in patients with moderate or severe renal impairment suggest that further studies in patients with mild renal impairment are not required. However, for studies of new agents where the PK of certain treatments may be affected by renal impairment, obtaining data from a patient population spanning a continuous range of $\mathrm{CrCL}$ levels and including patients with a complete series of renal function and impairment, may be an ideal approach.

The overall safety and AE profile of cabazitaxel observed in patients with normal or moderate renal impairment in this study was consistent with the known safety profile of cabazitaxel, and no new safety issues were identified. For the most frequently reported TEAEs, incidence rates were similar for patients with different levels of renal function. The low rate of AEs related to renal toxicity in patients with renal impairment suggests that renal function does not decrease during cabazitaxel treatment. The overall rate of grade 3-4 neutropenia in this study, based on laboratory assessments, was $84 \%$. This is similar to the rate of neutropenia reported in the phase III TROPIC trial (94\% all grades, $82 \%$ grade $3-4$ ) [14]. The overall rate of grade 3-4 febrile neutropenia in this study was $24 \%$, compared with $8 \%$ in TROPIC. This apparent difference could be due to the smaller number of patients, the heterogeneous patient population, or the more heavily pretreated patient population, in this phase I study compared with TROPIC.

Patients with mild-to-moderate renal impairment pose an increasingly frequent challenge for clinicians. Taking into consideration the results of this study and other studies assessing the PK and safety of treatments in patients with renal dysfunction, patients with renal impairment could be considered for entry into selected phase I studies of treatments with low renal clearance, where it is deemed unlikely that renal impairment would affect drug PK [26]. This will provide data for new agents in this patient population earlier and increase patient access to clinical trials and experimental treatments. Furthermore, results from such PK studies would inform regulatory authorities as to whether dose modifications should be recommended for certain patient subpopulations.

In summary, the data support the clinical recommendation that full doses of cabazitaxel $\left(25 \mathrm{mg} / \mathrm{m}^{2}\right)$ can be safely administered every 3 weeks to patients with mild-to-severe renal dysfunction.

Acknowledgements The authors would like to thank participating patients and their families, in addition to all staff at participating sites. The authors would like to acknowledge the assistance received from Gemma Sala (Clinical Trial Office Manager), Elisabet Sicart (Study Coordinator) and Laia Cano (Data Entry) in managing this clinical trial. This study was supported by Sanofi. The authors received editorial support in the form of medical writing services provided by Danielle Lindley of MediTech Media, funded by Sanofi. The authors were responsible for all content and editorial decisions and received no honoraria related to the development of this manuscript. The authors had full access to all of the data in the study and take responsibility for the integrity of the data and the accuracy of the data analysis. Javier Garcia-Corbacho acknowledges clinical fellowship support from SEOM. Experimental Cancer Medicine Centre (ECMC) and NIHR Biomedical Research Centre (BRC) funding is also acknowledged for the Cambridge Cancer Centre.

\section{Compliance with ethical standards}

Conflict of interest This study was sponsored by Sanofi. Analía Azaro, Jordi Rodón, Silvia Damian, Javier Garcia-Corbacho and Maja de Jonge have no conflicts of interest to disclose. Jean-Pascal 
Machiels has been a member of advisory boards for Boehringer Ingelheim (without compensation) and MSD, and received research grants from Novartis, Bayer and Janssen. Sylvie Rottey has been a member of advisory boards and received research funding from Sanofi. Richard Baird and Ron Mathijssen have received research funding from Sanofi. Pierre-François Clot, Claudine Wack, and Liji Shen are employees of Sanofi. Liji Shen is a stock holder of Sanofi.

Ethical approval All procedures performed in studies involving human participants were in accordance with the ethical standards of the institutional and/or national research committee and with the 1964 Helsinki declaration and its later amendments or comparable ethical standards.

Open Access This article is distributed under the terms of the Creative Commons Attribution 4.0 International License (http://creativecommons.org/licenses/by/4.0/), which permits unrestricted use, distribution, and reproduction in any medium, provided you give appropriate credit to the original author(s) and the source, provide a link to the Creative Commons license, and indicate if changes were made.

\section{References}

1. Aapro M, Launay-Vacher V (2012) Importance of monitoring renal function in patients with cancer. Cancer Treat Rev 38:235-240

2. Launay-Vacher V, Oudard S, Janus N, Gligorov J, Pourrat X, Rixe O, Morere JF, Beuzeboc P, Deray G (2007) Prevalence of Renal Insufficiency in cancer patients and implications for anticancer drug management: the renal insufficiency and anticancer medications (IRMA) study. Cancer 110:1376-1384

3. Launay-Vacher V, Etessami R, Janus N, Spano JP, Ray-Coquard I, Oudard S, Gligorov J, Pourrat X, Beuzeboc P, Deray G, Morere JF (2009) Lung cancer and renal insufficiency: prevalence and anticancer drug issues. Lung 187:69-74

4. Launay-Vacher V, Gligorov J, Le Tourneau C, Janus N, Spano JP, Ray-Coquard I, Oudard S, Pourrat X, Morere JF, Deray G, Beuzeboc P (2010) Prevalence of renal insufficiency in breast cancer patients and related pharmacological issues. Breast Cancer Res Treat 124:745-753

5. Launay-Vacher V, Ayllon J, Janus N, Spano JP, Ray-Coquard I, Gligorov J, Pourrat X, Morere JF, Beuzeboc P, Deray G, Oudard S (2009) Drug management of prostate cancer: prevalence and consequences of renal insufficiency. Clin Genitourin Cancer 7:E83-E89

6. Janus N, Oudard S, Beuzeboc P, Gligorov J, Ray-Coquard I, Morere J, Spano J, Pourrat X, Deray G, Launay-Vacher V (2009) Prevalence of renal insufficiency in cancer patients: data from the IRMA-2 study. J Clin Oncol 27:9559

7. Arellano J, Hernandez RK, Wade SW, Chen K, Pirolli M, Quach D, Quigley J, Liede A, Shahinian VB (2015) Prevalence of renal impairment and use of nephrotoxic agents among patients with bone metastases from solid tumors in the United States. Cancer Med 4:713-720

8. Bournakis E, Dimopoulos MA, Bamias A (2011) Management of advanced bladder cancer in patients with impaired renal function. Exp Rev Anticancer Ther 11:931-939

9. Finkel KW, Foringer JR (2007) Renal disease in patients with cancer. Nat Clin Pract Nephrol 3:669-678

10. Zhang Y, Zhang L, Abraham S, Apparaju S, Wu TC, Strong JM, Xiao S, Atkinson AJ Jr, Thummel KE, Leeder JS, Lee C, Burckart GJ, Lesko LJ, Huang SM (2009) Assessment of the impact of renal impairment on systemic exposure of new molecular entities: evaluation of recent new drug applications. Clin Pharmacol Ther 85:305-311
11. Vaughn DJ (2008) Chemotherapeutic options for cisplatin-ineligible patients with advanced carcinoma of the urothelium. Cancer Treat Rev 34:328-338

12. US Department of Health and Human Services Food and Drug Administration Center for Drug Evaluation and Research (CDER) (2010) Guidance for industry, pharmacokinetics in patients with impaired renal function: Study design, data analysis, and impact on dosing and labelling. Revised March 2010. http://www.fda.gov/downloads/Drugs/.../Guidances/ UCM204959.pdf. Accessed May 2016

13. European Medical Agency (2014) Guideline on the evaluation of the pharmacokinetics of medicinal products in patients with impaired renal function. Revised February 2014. http://www.ema.europa. eu/docs/en_GB/document_library/Scientific_guideline/2014/02/ WC500162133.pdf. Accessed May 2016

14. de Bono JS, Oudard S, Ozguroglu M, Hansen S, Machiels JP, Kocak I, Gravis G, Bodrogi I, Mackenzie MJ, Shen L, Roessner M, Gupta S, Sartor AO (2010) Prednisone plus cabazitaxel or mitoxantrone for metastatic castration-resistant prostate cancer progressing after docetaxel treatment: a randomised open-label trial. Lancet 376:1147-1154

15. Ridoux L, Semiond DR, Vincent C, Fontaine H, Mauriac C, Sanderink GJ, Oprea C, Kelly L, Clive S (2015) A phase I open-label study investigating the disposition of [14C]-cabazitaxel in patients with advanced solid tumors. Anticancer Drugs 26:350-358

16. Ferron GM, Dai Y, Semiond D (2013) Population pharmacokinetics of cabazitaxel in patients with advanced solid tumors. Cancer Chemother Pharmacol 71:681-692

17. Pivot X, Koralewski P, Hidalgo JL, Chan A, Goncalves A, Schwartsmann G, Assadourian S, Lotz JP (2008) A multicenter phase II study of XRP6258 administered as a 1-h i.v. infusion every 3 weeks in taxane-resistant metastatic breast cancer patients. Ann Oncol 19:1547-1552

18. QxMD Online Calculator (2015) Chronic kidney disease: epidemiology collaboration formula-Calculator to estimate glomerular filtration rate using the CKD-EPI (Chronic Kidney Disease Epidemiology Collaboration). http://www.qxmd.com/calculateonline/nephrology/ckd-epi-egfr. Accessed May 2016

19. Levey AS, Stevens LA, Schmid CH, Zhang YL, Castro AF III, Feldman HI, Kusek JW, Eggers P, Van Lente F, Greene T, Coresh $\mathrm{J}$ (2009) A new equation to estimate glomerular filtration rate. Ann Intern Med 150:604-612

20. Stevens LA, Schmid CH, Greene T, Zhang YL, Beck GJ, Froissart M, Hamm LL, Lewis JB, Mauer M, Navis GJ, Steffes MW, Eggers PW, Coresh J, Levey AS (2010) Comparative performance of the CKD Epidemiology Collaboration (CKD-EPI) and the Modification of Diet in Renal Disease (MDRD) Study equations for estimating GFR levels above $60 \mathrm{~mL} / \mathrm{min} / 1.73 \mathrm{~m} 2$. Am J Kidney Dis 56:486-495

21. National Cancer Institute (2010) Common Terminology Criteria for Adverse Events (CTCAE) version 4.03. http://evs.nci.nih. gov/ftp1/CTCAE/About.html. Accessed May 2016

22. de Bruijn P, de Graan AJ, Nieuweboer A, Mathijssen RH, Lam MH, de Wit R, Wiemer EA, Loos WJ (2012) Quantification of cabazitaxel in human plasma by liquid chromatography/triplequadrupole mass spectrometry: a practical solution for non-specific binding. J Pharm Biomed Anal 59:117-122

23. Lockhart AC, Sundaram S, Sarantopoulos J, Mita MM, WangGillam A, Moseley JL, Barber SL, Lane AR, Wack C, Kassalow L, Dedieu JF, Mita AC (2014) Phase I dose-escalation study of cabazitaxel administered in combination with cisplatin in patients with advanced solid tumors. Invest New Drugs 32:1236-1245

24. Mita AC, Denis LJ, Rowinsky EK, de Bono JS, Goetz AD, Ochoa L, Forouzesh B, Beeram M, Patnaik A, Molpus K, 
Semiond D, Besenval M, Tolcher AW (2009) Phase I and pharmacokinetic study of XRP6258 (RPR 116258A), a novel taxane, administered as a 1-hour infusion every 3 weeks in patients with advanced solid tumors. Clin Cancer Res 15:723-730

25. Dieras V, Lortholary A, Laurence V, Delva R, Girre V, Livartowski A, Assadourian S, Semiond D, Pierga JY (2013) Cabazitaxel in patients with advanced solid tumours: results of a Phase I and pharmacokinetic study. Eur J Cancer 49:25-34

26. Malik L, Mejia A, Weitman S (2014) Eligibility of patients with renal impairment for Phase I trials: Time for a rethink? Eur J Cancer 50:2893-2896

27. Takimoto $\mathrm{CH}$, Remick SC, Sharma S, Mani S, Ramanathan RK, Doroshow J, Hamilton A, Mulkerin D, Graham M, Lockwood GF, Ivy P, Egorin M, Schuler B, Greenslade D, Goetz A, Knight R, Thomas R, Monahan BP, Dahut W, Grem JL (2003) Doseescalating and pharmacological study of oxaliplatin in adult cancer patients with impaired renal function: a National Cancer Institute Organ Dysfunction Working Group Study. J Clin Oncol 21:2664-2672

28. Gibbons J, Egorin MJ, Ramanathan RK, Fu P, Mulkerin DL, Shibata S, Takimoto CH, Mani S, LoRusso PA, Grem JL, Pavlick A, Lenz HJ, Flick SM, Reynolds S, Lagattuta TF, Parise RA, Wang Y, Murgo AJ, Ivy SP, Remick SC (2008) Phase I and pharmacokinetic study of imatinib mesylate in patients with advanced malignancies and varying degrees of renal dysfunction: a study by the National Cancer Institute Organ Dysfunction Working Group. J Clin Oncol 26:570-576

29. Isambert N, Delord JP, Tourani JM, Fumoleau P, Ravaud A, Pinel MC, Petain A, Nguyen T, Nguyen L (2014) How to manage intravenous vinflunine in cancer patients with renal impairment: results of a pharmacokinetic and tolerability phase I study. Br J Clin Pharmacol 77:498-508

30. Mita AC, Sweeney CJ, Baker SD, Goetz A, Hammond LA, Patnaik A, Tolcher AW, Villalona-Calero M, Sandler A, Chaudhuri T, Molpus K, Latz JE, Simms L, Chaudhary AK, Johnson RD, Rowinsky EK, Takimoto CH (2006) Phase I and pharmacokinetic study of pemetrexed administered every 3 weeks to advanced cancer patients with normal and impaired renal function. J Clin Oncol 24:552-562

31. US National Institutes for Health (ClinicalTrials.gov) (2015) Pharmacokinetics and safety of regorafenib (bay73-4506) in cancer subjects with severe renal impairment. https://clinicaltrials. gov/ct2/show/NCT01853046. Accessed May 2016

32. Tan AR, Sarantopoulos J, Lee L, Reyderman L, He Y, Olivo MS, Goel S (2015) Pharmacokinetics (PK) of eribulin mesylate in cancer patients (pts) with normal and impaired renal function. J Clin Oncol 32:2595

33. Sanofi (2014) JEVTANA ${ }^{\circledR}$ (cabazitaxel) injection, Prescribing Information, FDA. http://products.sanofi.us/jevtana/jevtana.html. Accessed May 2016 